\title{
STORY THEATRE AND THE COMMUNICATION OF ADOLESCENT SEXUAL AND REPRODUCTIVE HEALTH: THE RAPE OF WOMANHOOD IN CALABAR, NIGERIA
}

\author{
Edisua Merab Yta ${ }^{1}$, Emmy Ikanaba Unuja Idegu $^{2}$ \\ ${ }^{1,2}$ Department Of Theatre, Film And Carnival Studies, University of Calabar, Nigeria. \\ gabrielmarce176@yahoo.com ${ }^{1}$
}

\begin{abstract}
Young people in Calabar have diverse sexual and reproductive health challenges. Many argue that integrating gender into health programming will help reduce some of these issues because gender is central to shaping many sexual and reproductive health issues. This study used story theatre, as a qualitatively, narrative and participatory approach in trying to understand how gender relates to and influences adolescent sexual and reproductive health. Twenty story sessions were held for a hundred young people (aged 10-19) in four selected communities' Akai Effa, Ikot Ekpo, Efut Uwanse and Nyakassang all situated in Calabar Municipality and Calabar South Local Government Areas of Cross River State, South-South Nigeria. Sessions were recorded and later coded and analyzed for sexual and reproductive health as well as gender themes. Key findings revealed that rape and gender-related sexual assault and violence, teenage pregnancy, intergenerational as well as the objectification of women ranked amongst the highest Adolescent Sexual and Reproductive Health (ASRH) and gender issues in the communities. Young females seem to be getting more of the negative effects than boys because they are seen as pleasurable and economic assets. It is recommended that out of the box approaches which will involve multi-systems and stakeholders be used in finding a solution to this worrisome issue.
\end{abstract}

Keywords: Story Theatre, Community, Rape, Womanhood.

\section{INTRODUCTION}

Reducing Adolescent Sexual and Reproductive Health Challenges is a global health concern. According to the World Health Organisation, adolescents are considered as persons between ages 10-19. A UNFPA fact sheet states that globally there are 1.8 billion adolescents and over one-fifth of this population live in sub-Saharan Africa (UNICEF 2014). Adolescent Sexual and Reproductive Health challenges affect the wellbeing of young people, especially in Sub-Saharan Africa. Adolescents continue to suffer a high burden of several sexual and Reproductive Health (SRH) challenges including, high rates of maternal mortality and morbidity, unintended pregnancies, unsafe abortions, Sexually Transmitted Infections (STIs), gender based violence and poor access to contraceptives. In fact, considering sub-Saharan Africa, that is the geographical location with the highest burden of HIV, adolescent girls and young women make up 57\% of persons living with HIV; and are twice more likely to be infected with HIV as compared to boys and young men (UNAIDS 2014).

Each year, almost 16 million adolescents aged 15-19 years give birth, constituting $11 \%$ worldwide, the majority of which occurs in developing countries. A report presented by WHO estimated that 3.9 million adolescent girls undergo an unsafe abortion and are exposed to various complications in pregnancy ((Black, Laxminarayan, Temmerman, \& Walker, 2016: 26). Research has shown that these negative health outcomes are driven by many factors such as poor economic resources, political policies and socio-cultural norms and practices. Many studies opine that social norms such as gender play a central role in shaping health outcomes. Gender according to Janet Momsen (2019) is the socially acquired notions of masculinity and feminity by which men and women are identified. 
Because these socio-cultural norms have an impact on women and men's sexual behaviour due to gender inequality, girls live in a restrictive world (e.g in their appearance, dressing, mobility, access to information, access to school and health care and so on), while the same cannot be said about the adolescent boys who are unconfirmed (Pincock 2018). Remaining a virgin, being an ambassador of their families, clan honour, being submissive in their sexual and intimate relationships and having limited knowledge or information concerning sexuality and reproduction is what is expected of adolescent girls, which is not the same for their male counterpart.

Gender norms in most cases stigmatize adolescent girls that are seen with contraceptives, become pregnant, are sexually abused through rape and sexual harassment or try to get information on sexuality. This makes it clear that gender norms are becoming more influential in determining adolescent health outcomes, especially as it concerns Adolescent Sexual and Reproductive Health (Kocsis 2017: 326).

A British council report on gender in Nigeria assesses key areas including employment and livelihoods, education, health, political representation and violence. It finds that women and girls suffer systematic disadvantage and discrimination that is magnified for those in the poorest states and sectors of the society. They have worse life chances than men and their sisters in comparable societies (Okoro \& Okoro 2009).

Cross River State, in the South-South geopolitical zone of Nigeria, is widely known as the tourist hub of Nigeria. It serves to project the image of the country and attracts a lot of foreign visitors that mix with the locals. Studying how gender influences ASRH of young people will be of help to several sectors in the state. A study was done in Calabar and Oban that examined the male role and other determinants of fertility behaviour revealed higher male percentage favoured polygamy, low educational attainment and socio-economics shaped parental decision about early and child marriage (Archibong 2020) Another study by UNFPA also reveals $65 \%$ of women of Reproductive age in Cross River State have experienced physical violence since age 15. Spousal violence is the highest in Cross River State placed at $47.4 \%$ and $25.4 \%$ of women in the state have experienced FGM (UNFPA 2016). Studying adolescents' individual experiences and how gender roles helped to shape their sexuality will be of utmost importance to all stakeholders. It is hoped that this study will help policy planners and designers in developing interventions that assist adolescents in improving their sexual, reproductive health and rights as well as the quality of their lives.

\section{METHODS}

The study was conducted as part of the TETFUND Institutional Based Research at the University of Calabar. Participants were recruited from four communities around Calabar and Cross River State, Nigeria viz: Akai Effa, Efut Uwanse, Ikot Ekpo and Nyakhassang. Inclusion criteria included youths between 10-19, parental consent and a willingness to freely express oneself. TETFUND Institutional Based Research management committee at the University of Calabar approved all the research procedures. Before the fieldwork, there was a four-day training for facilitators on issues of adolescent sexual and reproductive health, Gender, story theatre and creative drama methods. Facilitators were recruited from two non-governmental organizations; DreamBoat Theatre for Development Foundation and Communicating Development Initiative. UNFPA Cross River Office supported the project with information, education and communication products.

The study used qualitative tools that were narrative-based for a number of reasons. Luciana Herbert et al describe this aptly; Narratives provide an avenue for building trust 
between researchers and adolescents and also provide the nuance and detail needed to understand young people's experience (3). The study also used story theatre, dialogue and play way based research method to examine the effect of gender in shaping adolescent sexual and reproductive health in Calabar.

\section{RESEARCH PROCEDURE}

The study consisted of four phases; training of young participants on Adolescent Sexual and Reproductive Health, Gender and Storytelling using story circles to harvest stories on these project's themes, role-playing of selected stories and engagement with community members through story theatre sessions. Training on Adolescent Sexual and Reproductive Health, Gender and storytelling were to ensure that all participants had fair knowledge and understanding of these issues.

Story harvesting used story circles methodology. This basically was a group of 15-25 participants who sat in a circle and told real-life stories that were personal or about friends, relatives or neighbours. There was a story circle facilitator. The facilitator set the rules, described the circle's purpose and theme on daily basis, stated the time, helped participants listen to one another and coordinated the success of each story circle. It should be noted that sometimes participants chose to sing, recite a poem, some cried, some said nothing affirming silence in itself is a powerful tool of communication.

Each day participants discussed the stories told, they reflected upon the ones that caught their fancy. They identified common threads and similarities as well as differences. Each session lasted for 120minutes. After sessions project team managers were debriefed by facilitators. The manager provided additional coaching where necessary. Listening was a very important part of the story circle. At the story theatre level, participants selected some of the stories and role-played them, this involved rehearsals, characterization, acting with skeletal costumes and props. The stories selected were video recorded. Finally, the story theatre was presented in front of audience members from the communities. This allowed the story theatre participants to engage with their friends, parents and community members questioning some existing practices as regards to Adolescent Reproductive and Sexual Health as well as gender.

\section{THE ORETICAL FRAMEWORK}

This study draws upon many theoretical frameworks that dwelled upon the understanding of storytelling. The works of Bettelheim and Kearney argue that through the process of storytelling, participants gain many benefits including a better understanding of the world and therapeutic values. It also draws upon the theories of participatory drama such as Winifred Ward (the mother of Creative Drama). It places a lot of emphasis on selfexpression where play scripts are developed by the playing community out of their own thoughts, emotions and imaginations. Creative drama uses stories from popular culture. This emphasizing the understanding of self-society.

\section{CODING AND ANALYSIS}

Stories were written down by facilitators. They were later organized and sorted by other research team members that were not involved in facilitation. A code book was created by identifying various themes. To further validate and summarize data, quotations and excerpts were pulled out of the narratives to highlights and align with specific themes. The analysis produced several interesting findings, a number of themes emerged which will be discussed in the following pages. It is important to note that narrative excerpts provide an impression that is much more informative than mere variable labels (Rick Hoyle et al., 2002: 396). Coders were trained before working with the real narratives. 


\section{RESULTS/FINDINGS}

Twenty story theatre sessions were conducted between May and June 2020 with a hundred young people resulting in more than a hundred stories. These stories were analyzed, discussed and were passed through reflection. A number of themes were found to be woven across the stories of adolescent sexual and reproductive health and rights. These were driven by many factors including lean economic resources and traditional gender norms. Some of the adolescent sexual and reproductive health issues that were dominant are teenage pregnancy, rape, sexual harassment and abortion. Dominant gender issues include male child preference and the female child seen as an object for the pleasure and economic asset, intergenerational sex, gender-based violence and gender inequalities. The following are accounts of some of the stories.

\section{Rape and Gender-Related Sexual Harassment and Abuse}

Amongst the Adolescent Sexual and Reproductive health challenges occurring in our communities, rape and gender-related sexual abuse seem to be the highest. The young people in Akai Effa rated seven out of ten young girls to have been victims of this issue. Many of the stories told were about rape and sexual abuse. One young girl said "This rape issue is everywhere in the social media, people are talking, my friends are also talking about it, it is suffocating - many girls are suffering in silence" Here are some narratives that demonstrate that incestuous rape among stepfathers, stepbrothers, fathers, uncles etc. is increasing.

Story 1: Three of us were raped by our stepfather, our mum could do nothing because he threatened to leave her and reminded her that he had done her a favour by marrying her. We reported to the police, nothing happened. They said we were cursed, so we ran away, till today our mum does not know where we are. (Akai Effa)

Story 2: My neighbor raped his daughter \& poured acid on her in order to cover the crime. But she escaped death, neighbors reported the matter to the police and her father was arrested. (Ikot Ekpo)

Story 3: A Corper (National Youth Service Corps Member) serving in my school harassed me constantly, demanding to have sex with me. I was too afraid to agree because my mother had warned me against having sex before marriage. So, he bit me daily to accept his request. I reported him to some teachers, the Vice-Principal and the Principal but they all refused helping me. Rather, they asked me give it (sex) to him. I reported to the school counselor who then alerted the police. The principal, the Vice and teachers all defended the Corper when the Police came. The School Counselor then gave me her phone to record the Corper's conversation with me which she then used as evidence and got the Corper, the Principal and Vice arrested. The school was almost shut down. (Efut Uwanse)

Story 4. My neighbor, an elderly man befriended a woman and was raping her sixteen-year-old teenager. He got the teenage girl pregnant, when the mother found out, she left the man and drove her daughter out. The man rejected both of them and ran away with another woman. The teenage girl is stranded. (Akai Effa)

Story 5: My aunty was married and has a female child. The husband took a second wife and she had two children (one male and one female). The boy began to sexually harass his half-sister for a while. One day he pretended as if he was ill while others went to the farm to work. The half-sister was sent home to get work done before her 
father, step-mother and sister will return. The half-brother seized the opportunity to force and rape her. She reported the incident to her father and step-mother, but they did not believe her and did nothing about it. She was even infected (Nyakhasang)

Story 6: There was this woman on my street, she did not have a child, so her husband's people pressurized the husband to get a second wife and the first wife agreed to make her husband happy. The second wife came with two of her children (male and female) to her new home and they gave that first wife plenty of trouble. The first wife brought her little niece of about 12 years to stay with them. Eventually, the second wife was believed to be the one that poisoned the first wife. The 18 years old son of the second wife then made it a point of duty to consistently rape the 12 years old, but her aunties' husband and his second wife always accused her of being a prostitute and telling lies against their son. She eventually became pregnant and they drove her out of the house. She was living on the street till a good woman saw her and helped her till she delivered the child. (Nyakhassang)

Rape occurring in our communities is taking different forms, date rape, elderly men, teachers, incest, gang rape, all forms are within us. There are cases of elderly men who are also engaged in this act.

Story 7: A sixty-year-old man has been raping girls in our community. He pretends he wants to buy their goods-then calls them in and rapes them. People know but nobody is doing anything. My mum says it is shameful to talk about it (Akai Effa)

Story 8: One very old man calls girls, gives them money, then rapes them, telling them not to speak... my sister was used. What can we do? People are afraid that he is a juju man (Akai Effa)

Many schools are not safe as young people are abused by teachers who are supposed to model good characters.

Story 9: A geography teacher nicknamed the breast has been sexually harassing girls in our school. We have reported him, nothing has been done. He is still there. (Akai Effa)

Story 10: A teacher in Nursery fondles five-year-olds, when parents found out, he threatened to kill them if they spoke out. My aunty took him up-today they have removed him. (Ikot Ekpo)

Story 11: I am 17 years old, an SS3 female student in Calabar. I was a victim of sexual harassment in my school, a Secondary School in Calabar. The difficult thing for me was that it was from my Vice Principal. The teachers knew about it but no one was willing to help me against the Vice Principal. He paid my school fees at a time. Then one fateful day, he came to our classroom, asked everybody to go out and play except me. I stayed back on the class while the rest of my classmates left the class. He began telling me how he loved and felt emotionally aroused whenever he saw me. He said he paid my fees because he loved me so dearly that he could not resist me... he kept talking, started touching my body, breathing fast as his voice started shaking, telling me to please have sex with him. I resisted but he threatened to deal with me if I resisted. He became irresistible and started grabbing me hard. I was scared and shouted "Rape o! Rape o! some of my classmates ran into the class. My school Counselor also ran in to rescue me. She was surprised to see that it was the Vice- 
Principal. She called the police and the Vice Principal was arrested and sacked from the school. (Efut Uwanse)

Still, more teachers are involved in this practice

Story 12: Back then in my primary school there was this short Mathematics teacher that claimed he was also a pastor. He always behaved tough and will not even tell us his name. The teacher has been sexually harassing my classmates. A day came that we were having Mathematics class, but he did not come to class so one of our classmates went to call him in his office. When she entered his office, he locked her in and started fingering her to the point that she could not walk properly again. When she got home her mother noticed that she was not walking normally and asked her till she opened up to her. The mother reported the matter to the School and the teacher was sacked. The girl was also removed from the School (Nyakhassang)

Even some female teachers are not left out;

Story 13: One of our female teachers enjoys having sex with the male students in the school. She invites the big boys in our class and other senior classes into her office and starts doing rubbish with them. Friends tell us that she will undress and make them have sex with her and then warn them never to dare let anybody know about it. If any student tries to resist, she threatens to make the school hell for him. No student is courageous enough to report her to the Principal. They cannot even dare because she will forge a story against them and the school authority will always believe her and punish the student. The male students in the school are helpless as she does the rubbish with them every time (Efut Uwanse)

Date rape is also occurring in daily lives as many young girls are assaulted by people they know. Here are some stories.

Story 14: My friend went to a party with her boyfriend. He drugged her and raped her, she later became pregnant. He denied. She dropped out of school. My friend's parents threatened to kill him. He accepted the baby but he is a young boy, my friend is suffering (Akai Effa)

Story 15: Idara my sister was a 2nd year Microbiology student in the university. She met a boy on Facebook \& they became friends. She visited him in his house, was raped and killed. (Ikot Ekpo).

Story 16: Paulina went with her friends to a party. Her drink was drugged, after drinking she became unconscious and she was raped. (Ikot Ekpo)

Some forms of rape are not the regular type. A young boy had this to say

Story 17: I come from a poor home. A respected man in our neighborhood approached my parents seeking for my help in house chores, and he would in turn help pay my fees. Two weeks after I started, he began to make advances. He raped me again and again wounding my anus. I became ill but cannot tell my parents...please help me out as I do not want to be a gay. (Akai Effa)

And another

Story 18: I have a friend, his Father started raping him since he was six years and this continued till he is now 17 years. The father is now dead but how to come out of 
the act is his problem. He is now also involved in this act with both boys and girls, he rapes them when he has the opportunity

Young boys are being initiated into gay practices and girls, lesbianism. This practice is rising in our society as wealthy persons experiment all manners of sexual practices with both boys and girls. In Nyakhasang community, rape and gender-related sexual abuse seem to be ranked first of the top three Adolescent Sexual Reproductive and Reproductive health challenges occurring regularly in the community. Adolescents' stories revealed that eight out of ten young girls and 3 out of 10 young boys have experienced this unpleasant development. This practice is rising in communities probably due to poverty and peer influence and other factors that make people practice all forms of sexual orientations for both boys and girls, some willingly and some are victims.

There was hardly a story told without an incident of rape and sexual abuse being mentioned. One of the participants believes that the issue of rape and sexual abuse is on the increase in the community and it is not frowned at with stiff penalty given to culprits.

She says that "...most adolescents and women have now resigned to fate by keeping their experiences to themselves to avoid embarrassment. Some girls have even lost their lives and the funny thing is that is not only boys that are raping girls, some girls are also raped by their fellow girls, can you imagine that?"

Most of the rape cases were perpetrated by people within the communities who are very close to the victims and one of the consequences is that some occasions led to the death of the victims.

Story 19: I have witnessed my friend rape someone but I could not do anything. One night I was passing through my friend's family house and I heard a girl shouting for help, I rushed there thinking she needed help. But I was surprised to see that it was my friend that was raping a young girl in his room with no one to help. I left in disappointment and when I saw him the next day, I told him what he did was wrong and to my amazement, he asked me what my business was in the matter and that no one was complaining. He continued in the act till he raped one girl and she died, he is now in Police custody for murder (Male adolescent, Nyakhasang).

Rape is happening every day in our communities, more adolescent girls are being raped or molested not necessarily by people they know but by people related to people they know that they don't even know. This is brought to the fore by this story.

Story 20: There is a friend of mine who is a student at Big Qua Secondary School. Her best friend lent her a note and was not in school for some days She later went to the best friend's house to collect her note. When she arrived her best friend had gone to the market to get something, so her best friend's brother asked her to come and sit and wait for her. While waiting in the house, her best friend's brother came in and starting touching and seducing her, she struggled and shouted but no one was around. He raped her and she lost her virginity. She became pregnant, tried aborting the pregnancy with a local concoction and she died in the process.

Here's a case of acquaintance rape.

Story 21: My cousin Kokonne was 11 years old when she was raped by her uncle. She became pregnant and when she was due for delivery, she could not push the baby. So she died. (Ikot Ekpo) 
Story 22: I was just 3 years old when I was raped by my uncle. One day when my mother was bathing me, I complained of pains in my private part. I was taken to the hospital, a test was carried out and it was found out that I had an infection. I was treated but the matter went to court the rapist was jailed. I also live in a prison; I carry the scar. (Ikot Ekpo)

Rape occurs everywhere

Story 23: My friend Flora was raped and she lost her virginity. She took in and tried aborting the baby by taking overdose drugs to abort the pregnancy which caused over bleeding and she did not survive it. (Ikot Ekpo)

Story 24: My careless neighbour always leaves her daughter with another neighbour when she goes to work. The man has been raping her daughter, threatening to kill the girl if she tells her mother. Her mum later found out, she had an infection, later she died. (Ikot Ekpo)

\section{ANALYSIS OF FINDINGS}

The desecration of womanhood in Calabar has increasingly attracted concerns recently more than ever before. Rape cases are sometimes caused by the economic disadvantage the girl-child finds herself. Refer Story 8, Story 11 and Story 17 which exemplify how financial inducement played a major role in the defilement of the girls via rape or their naivety. It is for this reason, amongst others, that; "We need free education for the female because most are dropouts and poverty is the reason why they are having sex with men for money" - Female out of school (Esther, 29). In another assessment and or appraisal, it was observed that girls who, for whatever reason cannot be in school, should be encouraged with entrepreneurial activities thus; "Government should provide skill acquisition for females so that they can stop sleeping with older men for money" - Male out of School (Esther, 29). It is disinteresting to note that this social dislocation girls suffer in the hands of men cuts across races and nations. Advancing the economy as a strong reason for these acts, "... girls usually have sex with different boys because the boy you are dating might not have enough money and you go to have sex with another boy for money. The more money I get, the more beautiful I become. The boy you are dating may not want to have sex before marriage and you want to satisfy yourself" - FGDs, Kumbo Urban Number 9.

As bad as teenage/premarital sex is, it was also observed that older men who should ordinarily be role models to the girls take advantage of these girls, most of whom are younger than their own daughters. Very sadly, incestuous relationships exist to the chagrin of the victims. Stories 1, 2, 4, 5, 7, 8, 11, 17, 18, 21 and 22 records these damaging acts to womanhood in the study area. Again, related studies show that such acts cut across nationalities and cultures. Frankline et al., (2019: 171) write that; “...older men put us into pressure for sex. When you ask for something from old men they will demand sex before giving and will even give more money if you have sex with them" - FGD, Kekaikilaiki HA Number 10. Frankline et al..., (171) proceeds to add that; "....sex under pressure is very common in this community, and for young girls, it is the older men that take them as their partners. Because of the love for money, material things and also poverty, these young girls depend on these men for money and upkeep and thus these men take advantage over them" - IDI, Male Opinion leader, Kumbo Urban HA.

In some of the cases as reflected in the life stories encountered in the course of this research, girls so sexually assaulted ended up with teenage pregnancies with negative resultant effects. Here are some stories 
Story 25: I have a friend that likes following boys and does not listen to her mother's advice. She always says, I am a big girl, today she is pregnant and has stopped coming to school. (Akai Effa)

Story 26: Beatrice and I were in Primary School together but she was a bit older and much taller and bigger than most of us. Every day, on our way from school, she would stop over to spend the afternoon with this farmer in his farm which was along the road between our school and the community. After sometimes, we discovered that she was pregnant. She did not even regret it; she left school and did not even go back to write her Primary School Certificate Examination. She dropped out of school. Although the child died, she refused to go back to school. We started calling her Ma Primary 6, and until I left the village, her story had not changed. (Efut Uwanse)

Here are more stories

Story 27: There is this girl in my street, she lost her parent and decided to join bad company so she could raise money to take care of herself. As I speak she and her sisters are already mothers of two children because they are sleeping with different men to survive and when they made them pregnant, they abandoned them. They were used and dumped. (Nyakhassang)

Story 28: A Corper deceived my friend an SS3 student to sleep with him. He promised her good grades, gifts and even marriage and the girl fell into the trap. Later, she became pregnant and the Corper denied the pregnancy. She had to suffer. (Ikot Ekpo)

It is disheartening to note that while girls suffer the brunt, boys and men who are responsible hardly experience destiny dislocation as much as the girl victims. Kofi and Akwasi (18) agree with this when they submit that; "Girls carry pregnancy, take care of the babies and suffer from it. Boys only make the girls pregnant. If the boy is unemployed, he may ignore the girl..." - Rural Male Health worker (drug store) (Kofi and Akwasi, 18) In a number of cases, from teenage pregnancy some die out of attempted abortions and several others, having their destinies either avoidably delayed or even permanently truncated

Part of this study unbundled the uncomplimentary role teachers, in whose hands the students are placed for proper modeling, take advantage of them. Stories 3, 9, 10, 11, 12 , 13, 20. When girls are economically disadvantaged to go to school, there are problems; yet, even when parents, in spite of the economic hardship, manage to send their daughters to school, in a number of instances, their daughters become victims of rape and sexual slavery. Sometimes, under the guise of sex education, some teachers go wild with their female students. Much still needs to be done, not all teachers are qualified or trained in sex education. Some teachers are even having sex with students so how can they teach us sex education. Sex education should really be improved, we have recorded high birth rates in the past 2 years indicating that sex education has failed. Training teachers and empowering peer educators is important- FGDs, BBH HA, Number 10 (Frankline et al., 166).

\section{CONCLUSION}

Story theatre allowed the participants and research team to see the souls of the storytellers as they told the stories, sometimes in tears. It allowed participants to share their stories in deep ways without being judged. Participants saw how their identities as feminine and masculine imposed specific responsibilities, burdens, pains on their sexual and reproductive health and rights. Findings from the study suggest that solution would 
need a multi-faceted approach and perspectives, involving multiple stakeholders and systems. In the words of Luciana Herbert (16), it would require multi-pronged solutions and interventions addressing social, structural, educational and economic factors. Communities will need to recommit to making the world a safe place for women and young girls, they are threatened everywhere. People need to know that women's lives matter. Until the girl-child is effectively empowered educationally and or in entrepreneurial advantage, cases like these will reduce with snail speed.

\section{REFERENCES}

Archibong, N. (2012). Working Women and Spousal Violence in Nigeria: Emerging Patterns and Strategies for Change. In International Journal of Business and Social Science (Vol. 3, Issue 17). www.ijbssnet.com

Black, R. E., Laxminarayan, R., Temmerman, M., \& Walker, N. (2016). Reproductive, maternal, newborn, and child health. Washington, DC: World Bank Group.

Frankline, S. W., Dickson, S. N., Omer, N. \& Joseph, B. B. (2019). A Qualitative Analysis of Predictors of 'Sexo-Reproductive' Health Needs of Adolescent Girls in the Kumbo West Health District of Cameroon. Journal of Environmental Science and Public Health 3(1), 158-181

Hoyle, R. H., Harris, M. J., \& Judd, C. M. (2001). Research methods in social relations. Belmont Drive, CA: Wadsworth.

Joint United Nations Programme on HIV/AIDS (UNAIDS). (2014). Global HIV \& AIDS statistics- 2019. The New International ... http://www.unaids.org/sites/default/files/en/media/unaids/contentassets/documents/factshe et/2014/20140716_FactSheet_en.pdf

Kocsis, T. (2017). A Critical Analysis of Sexuality Education in the United States: Toward an Inclusive Curriculum for Social Justice. LMU/LLS Theses and Dissertations, 1178.

https://digitalcommons.lmu.edu/etd/470/

https://books.google.co.id/books?id=e_S2DwAAQBAJ\&pg=PA39\&lpg=PA39\&dq=Sexua 1+double+standards: + A+review+and+methodological+critique + of + two + decades + of + resea rch.+The+Journal+of+Sex+Research,+40(1),+13-26.+http://dx.doi

Momsen, J. (2019). Gender, health and violence. London: Routledge.

Okoro, C. C., \& Okoro, I. (2009). The use of medical information in nigeria: The influence of gender and status. Journal of Continuing Education in the Health Professions, 29(4), 254-258. https://doi.org/10.1002/chp.20044

Pincock, K. (2018). School, sexuality and problematic girlhoods: reframing "empowerment" discourse. Third World Quarterly, 39(5), 906-919. https://doi.org/10.1080/01436597.2017.1415141

UNFPA. (2016). Adolescent Girls in Disaster \& Conflict: Interventions for Improving Access to Sexual and Reproductive Health Services. Unfpa, 1-92.

UNICEF, W. U. U. (2014). Female genital mutilation fact sheet. WHOInternational/Reproductive Health., WHO/RHR/14(2014), 1-4. 